\title{
Akdeniz Üniversitesi Tıp Fakültesi Adli Tıp Anabilim Dalından Yaş Tayini İstenen Olguların Değerlendirilmesi
}

\author{
Evaluation of Cases Admitted for Age Determination to The Forensic Medicine \\ Department of Akdeniz University School of Medicine
}

\author{
Mehmet Atılgan', Murat Akkoyun ${ }^{2}$ \\ ${ }^{1}$ Akdeniz Üniversitesi Tıp Fakültesi Adli Tıp Anabilim Dalı, Antalya \\ ${ }^{2}$ Adli Tip Kurumu Adli Tıp Grup Başkanliğı, Antalya
}

\section{Özet}

Amaç: Yaş tayini antropolojik çalışmaların ve adli kimliklendirmenin önemli ve rutinde sık kullanılan bir parçasıdır. Bu çalışmada; 2002-2011 yılları arasında Akdeniz Üniversitesi Tıp Fakültesi Adli Tıp Anabilim Dalına yaş tayini istemi ile gönderilen canlı olguların özelliklerini ortaya koymak, elde edilen bulgular ve literatürler ışığında kullanılan yöntemi tartışmak ve yaş tayini konusunda ileride yapılacak çalışmalar için ülkemiz veri havuzuna katkıda bulunmak amaçlanmıştır.

Gereç ve Yöntem: Olguların, doğum yeri, cinsiyeti, kimlik yaşı, ifade ettiği yaş, rapor yaşı, gönderen kurumun türü, yaş tayinine gereksinim duyulan olayın niteliği, yaş tayini istenen kişilerin kimlik yaşları ve rapor yaşları araştıııldı. Rapor ve kimlik yaşları arasındaki farklar karşılaştırıldı.

Bulgular: İncelenen 10 yıllık dönemde 58'i (\% 28,3) erkek, 147'si $(\% 71,7)$ kadın olmak üzere toplam 205 yaş tayini istemi bulundu. 0-22 yaş grubundaki olgularda raporla tespit edilen yaşları ile kimlik yaşlar1 arasındaki ortalama fark 2,35’ti. Cinsel istismar/saldırı olgularında raporla tespit edilen yaşları ile kimlik yaşları arasındaki ortalama fark 2,21 iken kimlik yaşı ile iddia ettiği yaş arasında fark olmayan 57 olguda ise bu fark ortalaması 1,72 idi.

Sonuç: Sonuç olarak tespit edilen yaşlarla kronolojik yaşlar arasında istatistiksel olarak anlamlı farklar olduğu anlaşılmaktadır. Ülkemizin başka toplumlar için hazırlanmış yöntemleri uygulamak yerine kendi coğrafyasından seçilen yeterli sayıdaki örneklemlerle diş erüpsiyon ve mineralizasyon derecelerini de içerecek şekilde özgün bir yöntem oluşturulmasına ihtiyaç duyduğu açıktır.

Anahtar Kelimeler: Yaş tayini; Kemik yaşı; Adli tıp.

\section{Giriş}

Kimlik tayininin en önemli unsurlarından birisi kişinin yaşının belirlenmesidir. Yaş; cinsiyet, boy, vücut ağırlığ 1 , saç, cilt, göz rengi, parmak izi, kemik ve dişler gibi bireyin tıbbi kimliğini oluşturan fiziksel özelliklerden bi-

Sorumlu Yazar: Mehmet Atılgan

Akdeniz Üniversitesi Tip Fakültesi

Adli Tip Anabilim Dali, Antalya

E-posta: atilgan@akdeniz.edu.tr

Geliş:19.08.2016 Düzeltme:09.02.2017 Kabul:03.03.2017

\section{Abstract}

Objective: Age determination is an important procedure which is frequently used in anthropologic studies and daily practice of forensic medicine for identification. In this study, in live cases, we aimed; to determine characteristics of age determination cases referred to Forensic Medicine Department of Akdeniz University School of Medicine between 2002 and 2011 to discuss findings of used method by comparing literature and to provide data about age determination in purpose to lead future studies will be conducted in our country.

Materials and Methods: Birth places, gender, chronological age and claimed age, reported age, type of institution that requested an age determination, nature of event were all reviewed. We compared differences between reported ages and chronological ages.

Results: In 10 years of study period, 205 age determination were carried out where 58 of them were male $(28,3 \%)$ and 147 of them were female $(71,7 \%)$. The average difference between determined ages and ID ages was 2,35 in cases between 0-22 years old. Where in sexual abuse/assault cases the average difference between determined ages and chronological ages were 2,21, the average for confirmed chronological age cases were 1,72 .

Conclusions: As a conclusion, there is statistically significant difference between chronological and determined ages. We proposed that instead of using methods suitable for other societies, a unique method should be formed for Turks via examining also tooth eruption and mineralization levels in a sufficient number of eligible samples selected from the country.

Keywords: Age Determination; Bone Age; Forensic Medicine.

ridir. X-Ray'in bulunmasından sadece bir yıl sonra Von Ranke çocukların yaşının el radyografileri vasıtasıyla da incelenebileceği fikrini ileri sürmüştür (1). Sistematik çalışmaların en bilinenleri Greulich ve Pyle, Schmidt ve Moll ve Tanner ve ark. tarafindan yapılanlardır. Gelişmiş ülkelerde yaş tayini yalnız kimlik tayini maksadıyla yapıldığı halde, ülkemizde nüfus kayıtlarının zamanında yapılmaması nedeniyle kimlik tayininden daha çok kimliği bilinen kimselerin gerçek yaşlarının tespiti için yapılmaktadır (2). Özellikle kırsal alanda çocukların nüfusa geç 
kaydedilmesi ya da daha önceden kaydedilmiş çocuğun kaybı ve bu arada yeni bir çocuğun doğması sonucunda bir önceki çocuğun kimlik bilgilerinin devam ettirilmesi gibi durumlarla, kişilerin gerçek yaşlarından farklı kimlik yaşlarına sahip olduğu görülmektedir $(3,4)$.

Yaş tayini antropolojik çalışmaların ve adli kimliklendirmenin önemli ve rutinde sık kullanılan bir parçasıdır. (3-7) Ülkemizde Adli Tıp uygulamalarında yaygın olarak "Gök Atlası" ( Prof.Dr.Şemsi Gök ve arkadaşlarının 1985 yılında Greulich Pyle (G-P) atlası uyarlanarak oluşturdukları atlas) olmak üzere Greulich Pyle (G-P), Tanner Whitehouse (TW) ve batı toplumlarının standartlarına göre hazırlanmış atlaslar kullanılmaktadır $(2,8,9)$.

Akdeniz Üniversitesi Adli Tip Anabilim Dalında da yaş tayinlerinde boy, ağırlık, dişlerin durumu, sekonder seks karekterleri, kıllar, göz ve cilt bulguları ile birlikte kemik yaşının değerlendirilmesinde Gök Atlası kullanılmaktadır. Bu çalışmada yaşayan kişilerde yaş tayini istemiyle gönderilen olguların özellikleri ile birlikte kimlik yaşı, ifade edilen yaş ve tespit edilen yaşlar arasındaki farklar irdelenerek kullanılan yöntemin tartışılması amaçlanmıştır.

\section{Gereç ve Yöntem}

2002 - 2011 yılları arasındaki 10 yıllık dönemde Akdeniz Üniversitesi Tıp Fakültesi Adli Tıp Anabilim Dalına yaş tayini için gönderilen olgularda, cinsiyet, gönderen kurumun türü, yaş tayinine ihtiyaç duyulan olayın niteliği incelendi. En az iki öğretim üyesi ile Gök Atlası kullanılarak yapılmış olan kemik yaşı değerlendirmelerinde boy, ağırlık, dişlerin durumu, sekonder seks karakterleri, kıllar, göz ve cilt bulguları ile birlikte büyüme ve gelişmeyi etkileyen hastalıklar da dikkate alındı ancak olgularda bu tür bir hastalık belirtisine rastlanmadığından tüm olgular çalışma kapsamına alındı. Daha kesin bir yaş aralığı saptanabilen 0 - 22 yaş arası olgularda, cinsel istismar/saldırı olgularında ve kimlik yaşı ile iddia ettiği yaş arasında fark olmayan olgularda rapor ve kimlik yaşları arasındaki farklar karşılaştırıldı. Elde edilen verilerin istatistiksel analizleri SPSS-18 programı kullanılarak yapıldı.

\section{Bulgular}

İncelenen 10 ylllık dönemde 58'i (\% 28,3) erkek, 147 'si $(\% 71,7)$ kadın olmak üzere toplam 205 yaş tayini istemi vardı. Yaş tayinlerinin büyük kısmı $(\mathrm{n}=90, \% 43,9)$ Hukuk Mahkemeleri tarafindan istenirken bunu Ceza Mahkemeleri ( $\mathrm{n}=64, \% 31.2)$ ve Cumhuriyet Başsavcılıkları $(n=48, \% 23,4)$ izlemekteydi. Gönderen kurumlar her iki cinsiyet için ayrı ayrı değerlendirildiğinde kadın olgularda Ceza Mahkemelerinin öne çıktığı görüldü ( $\mathrm{n}=56$, \%38,1). Erkek olgular ise daha çok Hukuk Mahkemeleri tarafından gönderilmişti $(\mathrm{n}=45, \% 77,6)$ (Tablo 1).
Tablo 1. Olguların gönderen kurumlara ve cinsiyete göre dağılımı.

\begin{tabular}{|l|r|r|r|r|r|r|}
\hline \multirow{2}{*}{ Kurum } & \multicolumn{4}{|c|}{ Cinsiyet } & \multicolumn{2}{|}{} \\
\cline { 2 - 5 } & \multicolumn{2}{|c|}{ Erkek } & \multicolumn{2}{c|}{ Kadın } & \multicolumn{2}{|c|}{ Toplam } \\
\hline HM & 45 & 77,6 & 45 & 30,6 & 90 & 43,9 \\
\hline CM & 8 & 13,8 & 56 & 38,1 & 64 & 31,2 \\
\hline CBS & 3 & 5,2 & 45 & 30,6 & 48 & 23,4 \\
\hline Özel & 2 & 3,4 & 1 & 0,7 & 3 & 1,5 \\
\hline Toplam & 58 & 100,0 & 147 & 100,0 & 205 & 100,0 \\
\hline
\end{tabular}

CBS: Cumhuriyet Başsavcılıkları, CM: Ceza Mahkemeleri, HM: Hukuk Mahkemeleri; Özel:Dilekçe ile başvuru

Olay türlerinin gönderen kurumlara göre dağıllımı incelendiğinde cinsel istismar/saldırı vakalarının tamamının Cumhuriyet Başsavcılıkları ve Ceza Mahkemeleri tarafindan gönderildiği, Hukuk Mahkemeleri tarafindan gönderilen vakaların tamamının yaş tashihi vakaları olduğu görüldü (Tablo 2). Cumhuriyet Başsavcıllıkları tarafindan gönderilen vakaların \%95,8'i ( $\mathrm{n}=46)$, Ceza Mahkemeleri tarafindan gönderilen vakaların \%85,9'u $(n=55)$ cinsel istismar/saldırı olayı nedeniyle gönderilmiştir.

Hukuk Mahkemelerinden gelen ve kişisel olarak dilekçe ile başvuru yapan toplam 93 olgunun yaş tayini isteme nedenleri belirlenebilenleri arasında ilk sırayı bir işe girebilmek için yaş tayini isteyen olgular $(\mathrm{n}=13, \% 13,9)$, ikinci sırayı kardeşinin açtığı yaş tashihi davası sürecinde davayı lehte veya aleyhte desteklemek üzere yaş tayiniistenen $(\mathrm{n}=11, \% 11,8)$ olgular, üçüncü sırayı ise emeklilik ile ilgili istemler almaktayd $1(\mathrm{n}=7, \% 7.5)$.

Olay türleri incelendiğinde kadınlarda cinsel istismar/ saldırı olguları $(\mathrm{n}=97, \% 66,0)$ ilk sırada, yaş tashihi olguları $(n=46, \% 31,2)$ ikinci sırada görülürken, erkeklerde bu sıralama tam tersine dönmekle birlikte ilk sıradaki yaş tashihi olguları $(n=46, \% 79,4)$ ile ikinci sıradaki cinsel istismar/saldırı olguları $(\mathrm{n}=4, \% 7,0)$ arasında on katın üzerinde bir fark vardı (Tablo 3).

Daha kesin bir yaş aralığı saptanabilen $0-22$ yaş grubundaki 153 olguda raporla espit edilen yaşları ile kimlik yaşları arasındaki en düşük fark -2 , en yüksek fark +7 , ortalama fark $+2,35$ 'ti. 15 olguda $(\% 9,8)$ rapor yaşlarının kimlik yaşları ile uyumlu bulunduğu görüldü. (Tablo 4).

Toplam 101 cinsel istismar/saldır1 olgusunun 96's1 için düzenlenen raporda daha kesin bir yaş aralığ belirtilirken, 22 yaş üstü 5 olguda 22-25,25-45 gibi yaş aral1$\breve{g} 1$ şeklinde rapor verilmişti. Raporlarında daha kesin bir yaş aralı̆̆ belirtilen 96 cinsel istismar/saldırı olgusunun rapor yaşları ile kimlik yaşları arasındaki farklar incelendiğinde en küçük farkın $0(n=8, \% 8,3)$, en büyük farkın $6(\mathrm{n}=2, \% 2,1)$, ortalama farkın 2,21 olduğu görüldü Olguların $\% 8,3$ 'ünde $(\mathrm{n}=8)$ kimlik yaşları ile rapor yaşları uyumlu bulunurken, 29 olguda $(\% 30,1)$ rapor yaşı kimlik yaşından 2 yaş büyük bulundu. (Tablo 5). 
Tablo 2. Olay türlerinin gönderen kurumlara göre dağılımı.

\begin{tabular}{|c|c|c|c|c|c|c|c|c|c|c|}
\hline \multirow{3}{*}{ Olay Türü } & \multicolumn{8}{|c|}{ Gönderen Kurum } & \multirow{2}{*}{\multicolumn{2}{|c|}{ Toplam }} \\
\hline & \multicolumn{2}{|c|}{ CBS } & \multicolumn{2}{|c|}{$\mathrm{CM}$} & \multicolumn{2}{|c|}{$\mathrm{HM}$} & \multicolumn{2}{|c|}{ Özel } & & \\
\hline & Say1 & $\%$ & Say1 & $\%$ & Say1 & $\%$ & Say1 & $\%$ & Say1 & $\%$ \\
\hline Cinsel İstismar/ Saldırı & 46 & 95,8 & 55 & 85,9 & - & - & - & - & 101 & 49,3 \\
\hline Yaş Tashihi & - & - & - & - & 90 & 100,0 & 2 & 66,7 & 92 & 44,9 \\
\hline Belirtilmeyen & 1 & 2,1 & 2 & 3,1 & - & - & - & - & 3 & 1,5 \\
\hline Cinayet & - & - & 3 & 4,6 & - & - & - & - & 3 & 1,5 \\
\hline Cinayete Teşebbüs & - & - & 1 & 1,6 & - & - & - & - & 1 & 0,5 \\
\hline Darp & - & - & 1 & 1,6 & - & - & - & - & 1 & 0,5 \\
\hline Hirsızlık & - & - & 1 & 1,6 & - & - & - & & 1 & 0,5 \\
\hline Kimlik Çalma & 1 & 2,1 & - & - & - & - & - & - & 1 & 0,5 \\
\hline Kimlik Çıkarma & - & - & - & - & - & - & 1 & 33,3 & 1 & 0,5 \\
\hline Silahlı Yağma & - & - & 1 & 1,6 & - & - & - & - & 1 & 0,5 \\
\hline Toplam & 48 & 100,0 & 64 & 100,0 & 90 & 100,0 & 3 & 100,0 & 205 & 100,0 \\
\hline
\end{tabular}

CBS: Cumhuriyet Başsavcılıkları, CM: Ceza Mahkemeleri, HM: Hukuk Mahkemeleri, Özel:Dilekçe ile başvuru

Tablo 3. Olay türlerinin cinsiyete göre dağılımı.

\begin{tabular}{|c|c|c|c|c|c|c|}
\hline \multirow{3}{*}{ Olay Türü } & \multicolumn{4}{|c|}{ Cinsiyet } & \multirow{2}{*}{\multicolumn{2}{|c|}{ Toplam }} \\
\hline & \multicolumn{2}{|c|}{ Erkek } & \multicolumn{2}{|c|}{ Kadın } & & \\
\hline & Say1 & $\%$ & Say1 & $\%$ & Say1 & $\%$ \\
\hline Cinsel İstismar/Saldırı & 4 & 7,0 & 97 & 66,0 & 101 & 49,3 \\
\hline Yaş Tashihi & 46 & 79,4 & 46 & 31,2 & 92 & 44,9 \\
\hline Belirtilmeyen & 1 & 1,7 & 2 & 1,4 & 3 & 1,4 \\
\hline Cinayet & 2 & 3,4 & 1 & 0,7 & 3 & 1,4 \\
\hline Cinayete Teşebbüs & 1 & 1,7 & - & - & 1 & 0,5 \\
\hline Darp & - & - & 1 & 0,7 & 1 & 0,5 \\
\hline Hirsızlık & 1 & 1,7 & - & - & 1 & 0,5 \\
\hline Kimlik Çalma & 1 & 1,7 & - & - & 1 & 0,5 \\
\hline Kimlik Çıkarma & 1 & 1,7 & - & - & 1 & 0,5 \\
\hline Silahlı Yağma & 1 & 1,7 & - & - & 1 & 0,5 \\
\hline Toplam & 58 & 100,0 & 147 & 100,0 & 205 & 100,0 \\
\hline
\end{tabular}

Tablo 4. Daha kesin bir yaş aralığı saptanabilen 0 - 22 yaş grubundaki olgularda kimlik yaşlarına göre farkların dağılımı ve ortalama farklar.

\begin{tabular}{|c|c|c|c|c|c|c|c|c|c|c|c|c|c|}
\hline \multirow{2}{*}{$\begin{array}{c}\text { Kimlik } \\
\text { Yaşları }\end{array}$} & \multicolumn{10}{|c|}{ Fark (Rapor Yaşı - Kimlik Yaşı) } & \multirow{2}{*}{$\begin{array}{l}\text { Ortalama } \\
\text { Fark }\end{array}$} & \multirow[t]{2}{*}{ Medyan } & \multirow{2}{*}{$\begin{array}{c}\text { Toplam (\%) } \\
(\%)\end{array}$} \\
\hline & -2 & -1 & 0 & 1 & 2 & 3 & 4 & 5 & 6 & 7 & & & \\
\hline 3 & - & - & 1 & - & - & - & - & - & - & - & 0 & 0 & $1(0,7)$ \\
\hline 5 & 1 & - & - & - & - & - & - & - & - & - & -2 & -2 & $1(0,7)$ \\
\hline 6 & - & - & 1 & - & - & - & - & - & - & - & 0 & 0 & $1(0,7)$ \\
\hline 10 & - & - & - & - & 1 & - & 1 & - & - & 1 & 4,33 & 4 & $3(2,0)$ \\
\hline 12 & - & - & - & - & 2 & 1 & 2 & 2 & - & - & 3,57 & 4 & $7(4,6)$ \\
\hline 13 & - & - & - & - & 2 & 3 & 3 & 1 & 1 & 1 & 3,91 & 4 & $11(7,2)$ \\
\hline 14 & - & - & 1 & 3 & 7 & 4 & 3 & 1 & 1 & - & 2,6 & 2 & $20(13,1)$ \\
\hline 15 & - & - & 2 & 5 & 13 & 10 & 3 & 2 & 2 & 1 & 2,68 & 2 & $38(24,7)$ \\
\hline 16 & 1 & - & 2 & 10 & 2 & 11 & 1 & 1 & 1 & - & 2,07 & 2 & $29(18,9)$ \\
\hline 17 & - & 1 & 2 & 3 & 10 & 1 & 4 & - & - & - & 1,95 & 2 & $21(13,7)$ \\
\hline 18 & - & - & 1 & 5 & 2 & 1 & 1 & - & - & - & 1,6 & 1 & $10(6,5)$ \\
\hline 19 & - & - & 3 & 1 & 2 & - & - & - & - & - & 0,83 & 1 & $6(3,9)$ \\
\hline 20 & - & - & 1 & 2 & 1 & - & - & - & - & - & 1 & 1 & $4(2,6)$ \\
\hline 22 & - & - & 1 & - & - & - & - & - & - & - & 0 & 0 & $1(0,7)$ \\
\hline Toplam & 2 & 1 & 15 & 29 & 42 & 31 & 18 & 7 & 5 & 3 & 2,35 & 2 & 153 \\
\hline$\%$ & 1,3 & 0,7 & 9,8 & 18,9 & 27,4 & 20,2 & 11,8 & 4,6 & 3,3 & 2,0 & & & 100,0 \\
\hline
\end{tabular}


Tablo 5. Raporlarında daha kesin bir yaş aralığı belirtilen cinsel istismar/saldırı olgularının rapor yaşları ile kimlik yaşları arasındaki farklar.

\begin{tabular}{|c|c|c|c|c|c|c|c|c|c|c|}
\hline \multirow{2}{*}{$\begin{array}{l}\text { Kimlik } \\
\text { Yaşları }\end{array}$} & \multicolumn{7}{|c|}{ Fark (Rapor Yaşı - Kimlik Yaşı) } & \multirow{2}{*}{$\begin{array}{c}\text { Ortalama } \\
\text { Fark }\end{array}$} & \multirow[t]{2}{*}{ Medyan } & \multirow{2}{*}{$\begin{array}{c}\text { Toplam } \\
(\%)\end{array}$} \\
\hline & 0 & 1 & 2 & 3 & 4 & 5 & 6 & & & \\
\hline 12 & - & - & 1 & - & - & 1 & - & 3,5 & 4 & $2(2,1)$ \\
\hline 13 & - & - & 2 & 3 & 2 & - & - & 3 & 3 & $7(7,3)$ \\
\hline 14 & - & 3 & 5 & 3 & 2 & - & 1 & 2,57 & 2 & $14(14,6)$ \\
\hline 15 & 1 & 4 & 12 & 9 & 2 & 2 & 1 & 2,55 & 2 & $31(32,2)$ \\
\hline 16 & 2 & 7 & 1 & 5 & - & 1 & - & 1,81 & 1 & $16(16,7)$ \\
\hline 17 & 2 & 3 & 5 & 1 & 2 & - & - & 1,85 & 2 & $13(13,5)$ \\
\hline 18 & - & 4 & 2 & - & 1 & - & - & 1,71 & 1 & $7(7,3)$ \\
\hline 19 & 2 & 1 & 1 & - & - & - & - & 0,75 & 1 & $4(4,2)$ \\
\hline 20 & 1 & 1 & - & - & - & - & - & 0,5 & 1 & $2(2,1)$ \\
\hline Toplam & 8 & 23 & 29 & 21 & 9 & 4 & 2 & 2,21 & 2 & 96 \\
\hline$\%$ & 8,3 & 24,0 & 30,1 & 21,9 & 9,4 & 4,2 & 2,1 & & & 100,0 \\
\hline
\end{tabular}

Tablo 6. Kimlik yaşları ile iddia ettikleri yaş arasında fark olmayan olguların rapor yaşları ile kimlik yaşları arasındaki farklar.

\begin{tabular}{|c|c|c|c|c|c|c|c|c|c|c|}
\hline \multirow{2}{*}{$\begin{array}{l}\text { Kimlik } \\
\text { Yaşları }\end{array}$} & \multicolumn{7}{|c|}{ Fark (Rapor Yaşı - Kimlik Yaşı) } & \multirow{2}{*}{$\begin{array}{c}\text { Ortalama } \\
\text { Fark }\end{array}$} & \multirow[t]{2}{*}{ Medyan } & \multirow{2}{*}{$\begin{array}{l}\text { Toplam } \\
(\%)\end{array}$} \\
\hline & 0 & 1 & 2 & 3 & 4 & 5 & 6 & & & \\
\hline 12 & - & - & 1 & - & - & 1 & - & 3,5 & 4 & $2(2,1)$ \\
\hline 13 & - & - & 2 & 3 & 2 & - & - & 3 & 3 & $7(7,3)$ \\
\hline 14 & - & 3 & 5 & 3 & 2 & - & 1 & 2,57 & 2 & $14(14,6)$ \\
\hline 15 & 1 & 4 & 12 & 9 & 2 & 2 & 1 & 2,55 & 2 & $31(32,2)$ \\
\hline 16 & 2 & 7 & 1 & 5 & - & 1 & - & 1,81 & 1 & $16(16,7)$ \\
\hline 17 & 2 & 3 & 5 & 1 & 2 & - & - & 1,85 & 2 & $13(13,5)$ \\
\hline 18 & - & 4 & 2 & - & 1 & - & - & 1,71 & 1 & $7(7,3)$ \\
\hline 19 & 2 & 1 & 1 & - & - & - & - & 0,75 & 1 & $4(4,2)$ \\
\hline 20 & 1 & 1 & - & - & - & - & - & 0,5 & 1 & $2(2,1)$ \\
\hline Toplam & 8 & 23 & 29 & 21 & 9 & 4 & 2 & 2,21 & 2 & 96 \\
\hline$\%$ & 8,3 & 24,0 & 30,1 & 21,9 & 9,4 & 4,2 & 2,1 & & & 100,0 \\
\hline
\end{tabular}

Kimlik yaşları ile iddia ettikleri yaş arasında fark olmayan 57 olgunun rapor yaşları ile kimlik yaşları arasındaki farklar incelendiğinde en düşük farkın $-2(n=1$, $\% 1,8)$, en yüksek farkın $6(\mathrm{n}=2, \% 3,5)$, ortalama farkın 1,72 olduğu görüldü. En yüksek ortalama fark 12 yaş grubunda ( $\mathrm{n}=1)$ görülürken, en s1k müracaatın görüldüğü 15 yaş grubunda ortalama fark 2,38 idi. Sadece 6 vakada $(\% 10,5)$ rapor yaşı kimlik yaşı ile uyumlu bulunurken, olguların \%3,6'sında $(\mathrm{n}=2)$ rapor yaşı kimlik yaşından küçük, \%85,9'unda $(\mathrm{n}=49)$ rapor yaşı kimlik yaşından büyük olarak saptandı. Görülme sıklığı bakımından ilk sırayı $(n=18, \% 31,6)$ rapor yaşı ile kimlik yaşı arasında 1 ve 2 fark bulunan olgular paylaşmaktaydi. (Tablo 6).
Tüm olgularda Kolmogorov-Smirnov testi ile normal dağılıma uymadıkları anlaşılan iki bağımlı değişken (rapor yaşı ve kimlik yaşları) arasında istatistiksel olarak anlamlı bir fark bulunup bulunmadığının saptanması için uygulanan Wilcoxon testi sonucunda iki değişken arasındaki farkın anlamlı olduğu $(p<0,05)$ saptandı. Ayrıca ortalamalar arasındaki farkların anlamlı olup olmadığının belirlenmesi için yapılan Paired-Samples T Test (eşleştirilmiş iki grup arasındaki farkların testi) sonucunda iki ortalama arasındaki farkın istatistiksel olarak anlamlı olduğu bulundu $(\mathrm{p}<0,05)$.

\section{Tartışma}

Yaşayan bireylerde yaş tayininin dünyada en sık karş1laşılan uygulama alanları göçmenler, sığınmacılar, suçlular 
ve mağdurları, insan kaçakçıllğı ve çocuk pornografisi sorunlarıdır (10). Avrupada sınır ötesi göç, herhangi bir doğum belgesi olmayan yabancı sayısındaki artışa, bu durum da 199011 yılların ortalarından beri adli yaş tayini taleplerinde keskin bir artışa yol açmıştır (11). Avrupa ülkelerinde yaş tayininde ilk sırayı kimlik belgesi bulunmayan göçmenler alırken, ülkemizde çoğunlukla kimlikleri bilinen kişilerin gerçek yaşlarının tespiti için istenmektedir (2).

Yıldırım ve ark.nın (12) Gaziosmanpaşa Üniversitesi Tıp Fakültesi Adli Tıp Anabilim Dalına yaş tayini istemi ile başvuran 51 olguluk çalışmalarında erkek/kadın oranı bizim çalışmamızla (erkek/kadın oranı $1 / 2,5$ ) uygun şekilde 1/2,6 idi. Bu oran Baransel Isır ve ark.nın (13) Gaziantep Üniversitesi Tıp Fakültesindeki çalışmalarında 1/1,35 iken, 5 farklı Üniversitede yapılan çalışmalarında 1/1,14 olarak bulunmuştu (8). Büken ve ark.nın (9) 2003 yılında Düzce'de yaptıkları çalışmalarında incelenen 134 olgunun \%41'i kadınlardan, \%59'u erkeklerden oluşmaktaydı. Lynnerup ve ark. (14) tarafindan Danimarka'daki adli yaş tayinleri üzerinde yapılan çalışmada 165 olgunun \%81,2'si erkek iken, Santoro ve ark. (15) tarafindan İtalya'da yapılan 52 olguluk çalışmada \%78,9'unun erkek olduğu belirtilmiştir.

Yılmazer'in (3) Adli Tıp Kurumunda yaş tayininde kullanılan yöntemin verimlilik açısından değerlendirilmesi konulu tezinde yaş tayini için gönderilen dosyaların \%75,1'inin (n=622) Ceza Mahkemeleri, \%23,3'ünün $(n=193)$ Hukuk Mahkemeleri tarafindan gönderildiği belirtilmiştir. Büken ve ark.nın (9) çalışmalarında ise Hukuk Mahkemelerinden gelen olguların oran1 \%94,8 olarak saptanmıştır. Bizim olgularımızın ise \% 43,9'u Hukuk Mahkemeleri tarafından gönderilmiştir.

Cinsel istismar/saldırı olguları Y1lmazer'in (3) tez çalışmasında \%56,8 ile ilk sırada yer alırken, Yıldırım ve ark.nın (12) çalışmasında \%31,4 ile tashih olgularının $(\% 33,3)$ arkasında ikinci sırada bulunuyordu. Her iki çalışmada da bizim çalışmamızla uyumlu olarak erkek olguların yaş tayini istenme nedenlerinde birinci sırayı tashih davaları almaktaydı. Baransel Isır ve ark.nın (13) yaş tayini olgularının irdelendiği çalışmalarında olguların \%28'inin devlet memuriyetine girme, \%21'inin kimlik belgesi çıkarma ve \%14'ünün yurt dışına çıkma amacı olduğu belirtilmişti. Büken ve ark.nın (9) Düzce'de yürüttükleri çalışmada ise ilk sırayı $\% 28,4$ ile askerlik problemleri nedeniyle istenen yaş tayini olguları alıyordu. Çalışmamızda ise ilk sırada bir işe girebilmek için yaş tayini isteyen olgular $(\% 13,9)$ vard1.

Büken ve ark.nın (9) 2003 yılında Düzce'de yaptıkları yaş tayini istemlerini içeren çalışmalarında olguların \%9'unun tespit edilen yaşı, kimlik yaşı ile uyumlu; \%79,1'inde rapor yaşı, kimlik yaşından büyük bulunur- ken, en s1k görülen fark $(+3)$ olguların $\% 27,8$ 'inde saptanmıştı. Yıldırım ve ark.nın (12) Gaziosmanpaşa Üniversitesindeki çalışmalarında da rapor yaşı kimlik yaşından büyük ve $\% 75,7$ iken, bizim çalışmamızda daha kesin bir yaş aralığı saptanabilen olguların \%88,3'ünde rapor yaşı kimlik yaşından büyüktü. Çalışmamızda ayrıca; raporlarında daha kesin bir yaş aralığı belirtilen cinsel istismar/saldırı olgularının \%8,3'ünde $(n=8)$ kimlik yaşları ile rapor yaşları uyumlu iken geriye kalan olgularda $(n=88$, \%91,7) rapor yaşı kimlik yaşından büyüktü.

Baransel Isır ve ark.nın, (13) kimlik yaşının gerçek yaş olduğu kanaat edilen olguların çalışma kapsamına alındığı 2007 yılında yayınlanan çalışmalarında 13-22 yaş arası olguların \%29,6'sında kemik yaşı kronolojik yaşından küçük, \%22,2'sinde kemik yaşı kronolojik yaş ile uyumlu bulunurken olguların \%48'inde kemik yaşı kronolojik yaştan büyük bulunmuştu. 2009 yılında benzer şekilde seçilen vakalar üzerinde yaptıkları çalışmada ise 13-22 yaş grubundaki 406 vakanın \%9,6'sında kemik yaşı kronolojik yaşından küçük, \%10,6'sınde kemik yaşı kronolojik yaş ile uyumlu bulunurken olguların \%79,8'inde kemik yaşı kronolojik yaştan büyük bulunmuştu (8). Çalışmamızda ise kimlik yaşları ile iddia ettikleri yaş arasında fark olmayan olgular arasında sadece 6 olguda $(\% 10,5)$ rapor yaşı kimlik yaşı ile uyumlu bulunurken, olguların \%3,6'sında $(n=2)$ rapor yaşı kimlik yaşından küçük, \%85,9'unda $(n=49)$ rapor yaşı kimlik yaşından büyük olarak saptandı.

Metabolik bozukluklar, coğrafi farklar, sistemik hastal1klar, cinsiyet, beslenme, genetik özellikler, gebelik gibi durumların kemik gelişimini etkileyerek kişilerin saptanan yaşı ile nüfusa kayıtlı olduğu yaşı arasında farklılıklar ortaya çıkardığı bilinmektedir. Ancak çalışmamızdaki rapor yaşları ile kimlik yaşları arasındaki farkların diğer çalışmalara benzer şekilde genelde büyük, hatta bazen 7 yaşa kadar çıkmasının nedenleri arasında; ifadeler dışında kesin veriler olmamakla birlikte, daha çok resmi nüfus kayıtlarının düzenli olmaması, özellikle ebeveynlerin çocuklarını nüfusa oldukça geç yazdırmaları da olabileceğini düşünüyoruz.

Büken ve ark.nın (17) Gök Atlasının Türk çocuklar üzerinde uygulanabilirliğini belirlemek amacı ile 11-22 yaş aralığındaki 546 (298 erkek, 248 kız) olgunun planlı çekilen radyografileri değerlendirmek suretiyle yaptıkları çalışma sonucunda 19 ve 20 yaş grubundaki kadın olgular dışındaki tüm olgularda rapor yaşı ile kronolojik yaş arasında istatistiksel olarak anlamlı fark saptanmıştı. 22 yaş grubundaki erkek olgular hariç tüm yaş gruplarında atlasa göre tespit edilen yaşların ortalamaları, kronolojik yaşların ortalamalarından büyüktü. En büyük ortalama yaş farkı kadınlarda 14 yaş grubunda görülürken $(4,11 \pm 1,51)$, erkeklerde 15 yaş grubundayd $1(3,10 \pm 2,38)$. 
Büken ve ark.nın benzer şekilde Greulich-Pyle ve Tanner-Whitehouse (TW3) yöntemlerinin Türk çocuklarda yaş tayini için uygulanabilirliğini araştıran iki ayrı çalışmasında her iki yöntemde de kemik yaşı ve kronolojik yaş ortalamaları arasındaki farklar Gök Atlasındaki kadar yüksek olmamakla birlikte istatistiksel olarak anlamlı idi $(18,19)$.

\section{Sonuç}

Gerek bizim çalışmamız gerekse Türkiye'de günümüze kadar yapılan çalışmalarda Gök Atlası yöntemi ile tespit edilen yaşların kimlik yaşına göre 1-2 yaş fazla olmak şeklinde sapma gösterdiği anlaşılmaktadır. Ülkemizde G-P ve T- $W$ yöntemlerinin uygunluğuna ilişkin az sayıda literatür bulunmakla birlikte, bu yöntemlerin Gök Atlasına göre daha doğru sonuçlar verdiği ancak yine de kronolojik yaş ile tespit edilen yaşlar arasındaki farkların istatistiksel olarak anlamlı olduğu anlaşılmaktadır. Özellikle 12, 15 ve 18 gibi sınır yaşlarda \pm 1 düzeyindeki bir yanılgının bile tamiri olanaksız mağduriyetlere veya haksız kazanımlara yol açacağı göz önüne alındığında daha isabetli yaş tayini açısından başka toplumlar için hazırlanmış yöntemleri uygulamak yerine kendi coğrafyamızdan seçilen yeterli sayıdaki örneklemlerle özgün bir yöntem oluşturulması gerektiği düşünülmektedir. Yaş tayini yapılırken epifizlerin kapanma derecelerinin yanı sıra fiziksel ve ruhsal gelişim ile gerektiğinde diş erüpsiyon, mineralizasyon derecelerinin tespiti ve tüm bulguların birlikte değerlendirilmesinin bir seçenek olmaktan öte, zorunluluk olduğu aşikardır.

\section{Kaynaklar}

1. Schmeling A, Reisinger W, Geserick G, Olze A, Forensic Age Estimation of Live Adolescents and Young Adults. In: Tsokos M. ed. Forensic Pathology Reviews, Volume 5, Totowa, Humana Press; 2008: 269-288.

2. Baransel Isır A. Adli Hekimlikte Yaş Tayini. In: Koç S, Can M. eds. Birinci Basamakta Adli Tıp, İstanbul, 2. Bask1; 2011: 222-234 .

3. Yılmazer Ö. Adli Tıp Kurumu'nda Yaş Tayininde Kullanılan Yöntemin Verimlilik Açısından Değerlendirilmesi. Uzmanlık Tezi, T.C. Adalet Bakanlığı Adli Tıp Kurumu, İstanbul, 2006.

4. Uğur Ersoy Ö. Kemik Yaşının Değerlendirilmesi.0-18 Yaş Arası Popülasyonda Kesitsel Çalışma. Uzmanlık Tezi, T.C. Adalet Bakanlığı Adli Tıp Kurumu, İstanbul, 2003.

5. Çöloğlu AS. Adli Olaylarda Kimlik Belirlemesi. In:Soysal Z, Çakalır C. Eds. Adli Tıp, Cilt 1. Cerrahpaşa Tıp Fakültesi Yayınları. İstanbul; 1999: 73-92.
6. Üzel M. Türk popülasyonunda puberte dönemi kemik gelişimi ve yaş tayini üzerine anatomik ve radyolojik araştırma. Doktora Tezi, İ.Ü. Sağlık Bilimleri Enstitüsü Anatomi Anabilim Dalı, İstanbul, 2002.

7. Üzel M. Kemik Yaşı Belirlenmesi, Sosyoekonomik Faktörler ve Beslenme İlişkilerinin İncelenmesi. Uzmanlık Tezi, İ.Ü. Cerrahpaşa Tıp Fakültesi Anatomi Anabilim Dalı, İstanbul, 2002.

8. Baransel Isır A, Buken B, Tokdemir M, Dülger HE, Erel Ö, Fedakar R. 1998-2005 yılları arasında Türkiye'de 5 farklı bölgedeki üniversitelerin adli tıp anabilim dallarında raporlandırılan yaş tayini olgularının irdelenmesi. Türkiye Klinikleri Adli Tip Derg. 2009; 29(2): 304-313.

9. Büken B, Demir F, Büken E. 2001-2003 yılları arasında Abant İzzet Baysal Üniversitesi Düzce Tıp Fakültesi Adli Tıp Anabilim Dalı'na gönderilen yaș tayini olgularının analizi ve adli tıp pratiğinde karşılaşılan güçlükler. Düzce Tıp Fakültesi Derg. 2003; 5(2): 18-23.

10. Schmeling A, Black S. An Introduction to the History of Age Estimation in the Living. In: Black S, Payne JJ, Aggrawal A. Eds. Age Estimation in the Living. Chichester, UK. John Wiley \& Sons Ltd. 2010; 1-18.

11. Schmidt S, Koch B, Mühler B, Schmeling A. Optimizing the Thiemann-Nitz method for skeletal age determination for forensic age diagnostics in live subjects. Scand J Forensic Sci. 2007; 1: 1-32.

12. Yıldırım A, Çetin İ, Özer E, Gümüş B. Adli Tıp Anabilim Dalına 2006-2010 yılları arasında yaş tayini için başvuran olguların değerlendirilmesi. Çağdaş Tıp Derg. 2011; 1(2): 56-61.

13. Baransel Isır A, Dülger HE. 1998-2005 y1lları arasında Gaziantep Üniversitesi Adli Tıp Anabilim Dalında raporland1rılan yaş tayini olgularının irdelenmesi. Türkiye Klinikleri Adli T1p Derg. 2007; 4(1): 1-6.

14. Lynnerup N, Belard E, Buch-Olsen K, Sejrsen B, Damgaard-Pedersen $\mathrm{K}$. Intra- and interobserver error of the Greulich-Pyle method as used on a Danish forensic sample. Forensic Sci Int. 2008; 179: 242-242.

15. Santoro V, De Donno A, Marrone M, Campobasso CP, Introna F. Forensic age estimation of living individuals: A retrospective analysis. Forensic Sci Int. 2009; 193: 129-129.

16. Türk Medeni Kanunu. Resmi Gazete Sayı 24607, Kanun Numaras1: 4271. Kabul Tarihi: 22/11/2001.

17. Büken B, Büken E, Şafak AA, Yazıcı B, Erkol Z, Mayda AS. Is the Gök Atlas sufficiently reliable for forensic age determination of Turkish children? Türkiye Klinikleri Adli Tip Derg. 2008; 38(4): 319-327.

18. Büken B, Şafak AA, Büken E, Yazıcı B, Erkol Z, Erzengin ÖU. Is the Tanner-Whitehouse (TW3) method sufficiently reliable for forensic age determination of Turkish children? Türkiye Klinikleri Adli Tıp Derg. 2010; 40 (5): 797-805.

19. Büken B, Şafak AA, Yazıcı B, Büken E, Mayda AS. Is the assessment of bone age by the Greulich-Pyle method reliable at forensic age estimation for Turkish children? Forensic Sci Int. 2007; 173(2-3): 146-153. 